\title{
Positive interactions between suspension-feeding bivalves and seagrass - a facultative mutualism
}

\author{
Bradley J. Peterson ${ }^{1, *}$, Kenneth L. Heck Jr ${ }^{2}$ \\ ${ }^{1}$ Department of Marine Sciences, University of South Alabama, Mobile, Alabama 36688, USA \\ ${ }^{2}$ Dauphin Island Sea Laboratory, PO Box 369-370, Dauphin Island, Alabama 36528, USA
}

\begin{abstract}
In shallow coastal waters, suspension-feeding bivalves often dominate the benthos in numbers as well as biomass. In the Gulf of Mexico and the Caribbean Sea, these filter feeders are usually associated with seagrass. Two simultaneously conducted field experiments (a mussel density manipulation and a mussel predation experiment) were conducted to examine the potential positive interactions between the suspension-feeding mussel Modiolus americanus (Leach) and the seagrass Thalassia testudinum Banks ex König. The mussel density manipulations resulted in a doubling of the total nitrogen and total phosphorus levels of sediments, and a significant reduction in leaf tissue $\mathrm{C}: \mathrm{N}, \mathrm{N}: \mathrm{P}$ and $\mathrm{C}: \mathrm{P}$ ratios, demonstrating that the mussels increased the sediment nutrient content and that these increased nutrients were biologically available to the plant. T. testudinum responded to the presence of mussels by significantly increasing leaf widths and lengths. In addition, productivity significantly increased in the mussel-addition treatments. Another response to the presence of mussels included a significantly reduced epiphytic load on the seagrass leaves. The mussel predation experiment evaluated the effects of seagrass on the survivorship of the associated mussel, $M$. americanus. Mean survival was significantly greater in vegetated habitats than in unvegetated sediments. Consequently, when mussels are present in seagrass meadows, they elevate seagrass productivity through either increased nutrient resource pools or reduced epiphytic loads on the leaves, while the seagrass increases mussel survivorship. Thus, this study demonstrates the reciprocal positive interactions of these organisms when associated and suggests that seagrass meadows may exist as a mosaic of nutrient and productivity 'hot spots' when suspension-feeding organisms are present. These positive interactions may have important consequences in the development, structure and organization of seagrass communities.
\end{abstract}

KEY WORDS: Bentho-pelagic couple $\cdot$ Habitat complexity · Plant-animal interactions · Seagrass · Thalassia testudinum $\cdot$ Suspension-feeding bivalves $\cdot$ Modiolus americanus $\cdot$ Facultative mutualism

\section{INTRODUCTION}

Suspension-feeding bivalves occur in high densities in many estuaries. In coastal systems, suspension-feeding bivalves show strong interactions with the overlying water column by filtering particles and by ex-

\footnotetext{
*Present address: Department of Biological Sciences and the Southeast Research Center, Florida International University, University Park, Miami, Florida 33199, USA.

E-mail: petersob@fiu.edu
}

creting nutrients in the form of ammonium and phosphorus (Verwey 1952, Widdows et al. 1979, Jordan \& Valiela 1982, Wright et al. 1982, Bertness 1984, Wildish \& Kristmanson 1984, Frechette \& Bourget 1985, Kautsky \& Evans 1987, Jørgensen 1990, Small 1991). Filterfeeders transform suspended material by changing particle size distributions in the water column and by converting particulate material into dissolved constituents or biomass via metabolism (Dame et al. 1980, Dame \& Dankers 1988). Dame et al. (1985) suggested that bivalve aggregates may act as positive feedback 
loops in which particulate nitrogen (phytoplankton) consumed by the suspension-feeding bivalves is rapidly remineralized into ammonium $\left(\mathrm{NH}_{4}\right)$, which is then available for plant growth. Such a feedback mechanism has been envisioned as both a nitrogen retention mechanism as well as a process that accelerates the nitrogen cycle (Dame et al. 1984,1989). In addition, organic deposits associated with suspension-feeding bivalves are of special importance for the remineralization of nutrients because processes of phosphorus release are promoted in anaerobic environments (Jansson \& Wulff 1977, Holm 1978, Nixon et al. 1980). Previous studies have demonstrated that sedimentation of fecal organic material provides a considerable input of phosphorus to the sediment surrounding suspension-feeders (Sornin et al. 1986, Dame et al. 1989). This phosphorus pool within the sediments can provide a source of phosphate for a diffusion flux out of the sediment for many years (Nixon et al. 1980).

The studies cited above have generated great interest concerning the impact that suspension-feeding bivalves have on phytoplankton growth dynamics. However, the influence that suspension-feeding bivalves have on submerged and emergent aquatic vegetation has not been studied as well. Mechanistically, it seems likely that as suspension-feeding bivalves transfer planktonic production from the water column to the benthos via feces and pseudofeces, they may elevate submerged aquatic vegetation growth and productivity by increasing the nutrients available in the rhizosphere. Bertness (1984) investigated the interaction of cordgrass Spartina alterniflora and the semi-infaunal mussel Geukensia demissa, and demonstrated that the presence of this mussel at densities as high as 900 ind. $\mathrm{m}^{-2}$ increased $S$. alterniflora net production and the above- to belowground biomass ratio. Recently, Reusch et al. (1994), working with the blue mussel Mytilus edulis and the eelgrass Zostera marina, found that sediment porewater concentrations of ammonium and phosphate doubled in the presence of mussels and suggested that the mussels fertilize eelgrass growth by the deposition of feces and pseudofeces. Similarly, Reusch \& Williams (1998) demonstrated that the introduced mussel, Musculista senhousia, fertilized beds of $Z$. marina at moderate densities of individuals. However, when densities of mussels increased, M. senhousia impaired rhizome elongation.

In addition to the possible direct effect that porewater nutrient enrichment may have on the growth of submerged aquatic vegetation, several possible indirect effects of suspension-feeding bivalves on seagrasses may also exist. The presence of suspension-feeding bivalves increases the structural complexity of the habitat. The spaces between shells of adjacent mussels may provide a predation refuge, reducing predation pressures on epiphytic grazer species such as small gastropods and amphipods. Increased densities of epiphytic grazers could then lead to an increased amount of epiphytic grazing from seagrass leaves, which consequently might lead to an increase in leaf light absorption. Orth \& van Montfrans (1984) provided evidence suggesting that the presence of a periphyton grazer can have substantial (indirect) impact on the proliferation, biomass and reproductive potential of seagrasses. Consequently, a model can be envisioned in which 2 different mechanisms, nutrient enrichment and increased light absorption, both due to the presence of bivalve suspension-feeders, can synergistically affect seagrass productivity. Currently, neither mechanism has been sufficiently tested experimentally; but if strong effects exist, then suspension-feeding bivalves may create microzones of increased productivity within seagrass assemblages.

One conspicuous plant-animal association within seagrass habitats of the Gulf of Mexico and Caribbean Sea involves the turtle grass Thalassia testudinum Banks ex König, and the semi-infaunal suspension-feeding tulip mussel Modiolus americanus (Leach) (Rodriguez 1959, Jackson 1973, Strömgren 1976, Andrews 1977, Lyons 1989, Young 1989, Valentine \& Heck 1993). Using density manipulations of mussels, the following questions were addressed: (1) Does the presence of $M$. americanus affect $T$. testudinum shoot density, biomass (above- or belowground), or productivity? (2) Does the presence of mussels increase nutrient content of the pore-water? (3) Does increased habitat complexity, resulting from the presence of mussels, elevate epiphyte grazer populations? and the corollary (4): if (3) is true, does mussel presence reduce epiphyte coverage on seagrass blades via increased epiphyte consumption by associated grazers? Finally, by manipulating seagrass aboveground biomass and transplanting marked bivalves into different locations, 2 remaining questions were addressed: (5) Does the the presence of T. testudinum affect the survival of M. americanus? (6) Is there evidence of a mutualistic association between turtle grass and tulip mussels?

\section{METHODS}

The effects of the presence of the semi-infaunal suspension-feeding mussels Modiolus americanus on Thalassia testudinum were observed in St. Joseph Bay, Florida, in the northeastern Gulf of Mexico $\left(30^{\circ} 00^{\prime} \mathrm{N}\right.$, $85^{\circ} 30^{\prime} \mathrm{W}$ ) (Fig. 1). St. Joseph Bay is a protected shallow coastal embayment where salinities usually range from 30 to $36 \%$ (Stewart \& Gorsline 1962, Folger 1972, this study). The mean depth is $3 \mathrm{~m}$. Temperatures vary seasonally from approximately 8 to $30^{\circ} \mathrm{C}$ (this study), and 


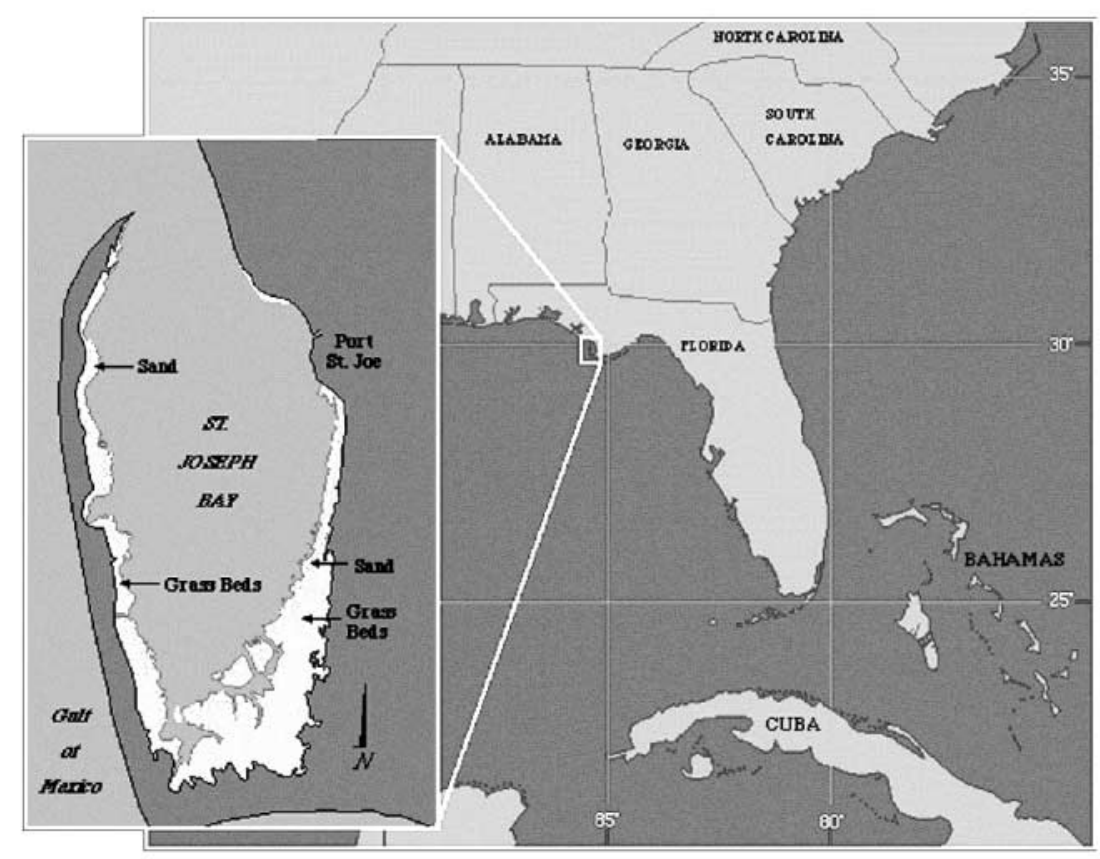

Fig. 1. Site location and map of the study site, in St. Joseph Bay, Florida

sible translocation of stored nutrients through the seagrass rhizomes out of or into the plots was prevented by severing the rhizomes around the perimeter of each plot. This was repeated every 3 mo. All native mussels in the plots were removed prior to the initiation of the experiment. This experiment was conducted for $1 \mathrm{yr}$. It was initiated on September 18, 1996, and concluded on September 21, 1997.

Mussels were added randomly to plots at treatment densities of 0 , 500 and 1500 individuals $\mathrm{m}^{-2}(\mathrm{n}=3$ for each density at each location; $\mathrm{n}=6$ for each treatment). Within $7 \mathrm{~d}$ of planting, the mussels had reattached themselves into natural positions. These densities approximate the range of abundances most often observed in the bay (Valentine \& Heck 1993). Previous investigations have demonstrated that ingestion

the mean tidal range is $0.5 \mathrm{~m}$ (Rudloe 1985). The bay is oligotrophic, with water-column nitrogen and phosphorus values seldom exceeding 3 and $0.2 \mu \mathrm{M}$, respectively. Phytoplankton abundance is also low, usually below $5 \mu \mathrm{g} \mathrm{l}^{-1}$. Therefore, the light available for seagrasses is high, with approximately $40 \%$ of measured light at the water surface reaching the seagrass canopy (this study).

St. Joseph Bay supports an extensive seagrass habitat occupying some $26 \mathrm{~km}^{2}$ of shallow bay bottom (McNulty et al. 1972). This seagrass habitat is dominated by large monospecific stands of Thalassia testudinum interspersed with smaller patches of Halodule wrightii, unvegetated sand flats and small amounts of Syringodium filiforme (Iverson \& Bittaker 1986). Seagrass production is highly seasonal, with shoot biomass and density peaking near $150 \mathrm{~g}$ ash-free dry weight (AFDW) $\mathrm{m}^{-2}$ and 3000 shoots $\mathrm{m}^{-2}$, respectively, during the summer months (Iverson \& Bittaker 1986). Only the shallowest portions of the seagrass habitat are exposed during low tides, and wave energy is minimal. Associated with these $T$. testudinum beds is the semi-infaunal tulip mussel Modiolus americanus, which is found in densities as high as 2000 ind. $\mathrm{m}^{-2}$ and at a mean density of 625 ind. $\mathrm{m}^{-2}$ (Valentine \& Heck 1993).

Mussel-density manipulations. Density manipulations of mussels were performed in 2 arrays of 9 randomly assigned $0.5 \mathrm{~m}^{2}$ plots. Each array was spatially separated (approx. $1.6 \mathrm{~km}$ ) within the bay in a heavily vegetated portion of a turtle grass meadow. Plot margins were marked by anchoring PVC frames to the sediment. Pos- rates of suspension-feeding bivalves are size-dependent (Frechette \& Bourget 1985); therefore, mussels of similar length (45 to $50 \mathrm{~mm}$ ) were used in this experiment. A linear regression of shell length to gram dry weight was constructed for Modiolus americanus. This allowed a more precise comparison to be made as $\mathrm{g}$ dry wt tissue $\mathrm{m}^{-2}$ rather than as ind. $\mathrm{m}^{-2}$.

Mussel-treatment effects on short-shoot (SS) density, aboveground biomass, leaf morphometrics, leaf productivity and epiphyte coverage were compared monthly by marking and then collecting all SS from randomly selected $0.01 \mathrm{~m}^{2}$ sub-samples from each replicate plot during 1 growing season $(6 \mathrm{mo})$. Leaf production was measured by a modified leaf marking method (Zieman 1974). Within each $0.01 \mathrm{~m}^{2}$ quadrat, all short shoots of the seagrass were marked near the base of the leaves by driving an 18-gauge hypodermic needle through all of the leaves on a short shoot. The marked shoots were allowed to grow for 10 to $14 \mathrm{~d}$, after which all aboveground seagrass material in the quadrats was harvested. In the laboratory, the number of leaves, leaf width, leaf length, daily gross aboveground production, aboveground seagrass biomass, SS density, and leaf epibiont biomass $\left(\right.$ shoot $\left.^{-1}\right)$ were determined from the harvested shoots. Epibiont mass was determined by scraping fouling organisms and algae from each leaf then drying them to a constant mass $( \pm 0.01 \mathrm{mg})$ in an oven at $60^{\circ} \mathrm{C}$. Following dry weighing, the ash weight was determined by ashing the samples at $500^{\circ} \mathrm{C}$ for $4 \mathrm{~h}$. AFDW was calculated as dry weight - ash weight. 
Additionally, belowground biomass was collected bimonthly for $1 \mathrm{yr}$ with a PVC coring device $(5.1 \mathrm{~cm}$ diameter, $15 \mathrm{~cm}$ depth, $1.5 \%$ of plot area). Sediment plugs were refilled immediately with clean sand. Belowground biomass was calculated by drying seagrass rhizomes and roots to a constant mass $( \pm 0.01 \mathrm{mg})$ at $60^{\circ} \mathrm{C}$. Following drying, AFDW was obtained as described above. Epiphyte grazers were collected bimonthly for 1 growing season by suction-sampling the area enclosed by a PVC cylinder $(15.24 \mathrm{~cm}$ in diameter $\times 150 \mathrm{~cm}$ in height) placed haphazardly on the sediment surface. The sample was passed through a $0.5 \mathrm{~mm}$ sieve and each individual was identified and recorded.

Sediment nutrient concentrations were collected bimonthly for $1 \mathrm{yr}$ with a PVC core $(2 \mathrm{~cm}$ diameter, $15 \mathrm{~cm}$ depth). The sediment samples were dried at $80^{\circ} \mathrm{C}$ for at least $24 \mathrm{~h}$ and homogenized by milling to a fine powder. Total carbon and nitrogen contents of the sediment samples were determined for each treatment by oxidation in a Carlo Erba Model 1500 CNS analyzer. Phosphorus content was measured using the dry oxidation-acid hydrolysis procedure described in Fourqurean et al. (1992a) for total particulate phosphorus determination.

To document any potential changes in $\mathrm{N}$ and $\mathrm{P}$ concentrations in leaves due to treatment effects, biomass specific changes in the concentrations of $\mathrm{C}, \mathrm{N}$ and $\mathrm{P}$ in the dried leaves were measured following Fourqurean et al. (1992a). Five randomly selected SS were selected from each treatment at the initiation of the experiment (September 1995), at the beginning of the growing season (May 1996), and at the conclusion of the experiment (September 1996). Leaves were gently scraped and washed in flowing tap water to remove epibionts and sediments that had adhered to the leaves. These washed samples were dried to a constant mass and homogenized by milling to a fine powder. The elemental contents of $\mathrm{C}, \mathrm{N}$ and $\mathrm{P}$ of these seagrass leaves were then determined as described above. The data are presented as mol:mol ratios.

If no re-sampling of any area within the treatment plots occurred over the course of the entire experiment, $60 \%$ of the total plot area would be sampled (destructive and non-destructive sampling). However, destructive sampling (removing plant material) would affect only $20 \%$ of the plot area over the course of the experiment. The repeated sampling experimental design was used to determine the initial size of the treatment plots.

Test of Thalassia testudinum as a predation refuge. To test whether Thalassia testudinum provided a predator refuge for Modiolus americanus, we manipulated the structural complexity of the canopy. We compared mussel survival in 3 areas: the natural seagrass bed of $T$. testudinum (natural), $T$. testudinum with above- ground biomass clipped to the sediment surface (clipped), and unvegetated sand (unvegetated). The clipped T. testudinum treatments allowed the protection of the emergent blades to be compared to that of the roots and rhizomes. We used an intermediate density (1000 ind. $\mathrm{m}^{-2}$ ) for this experiment. Individuals of M. americanus were collected haphazardly within the bay and marked with numbered tape. Three hundred individuals were randomly assigned to groups of 10 individuals placed into 10 replicate $0.01 \mathrm{~m}^{2}$ plots $(\mathrm{n}=$ 100 ) in each treatment area. Mussels were planted to natural depths $(3 / 4$ of their shell length) within the sediment. After $10 \mathrm{~d}$ survivorship was recorded.

Statistical analysis. This study consisted of 2 experiments: a mussel density manipulation at 3 different levels $\left(0,500\right.$ and 1500 ind. $\left.\mathrm{m}^{-2}\right)$ and a predation experiment between 3 different levels of plant structure (none, belowground only, and above- and belowground). Each plot was followed through time, therefore repeated-measures ANOVA was used. When we found a significant effect on the response variable, multiple comparison tests (Tukey's Studentized range) were used to test for significant differences between levels within the treatment. One-way ANOVA was used to test between the 2 locations for each response variable. Since there were no significant differences between the 2 locations, the replicates were pooled. All ratios were arcsine-transformed prior to statistical analysis. One-way ANOVA was used to test for significant differences between the 3 habitat types for the predation experiment. Repeated-measures ANOVA and 1-way ANOVA results were considered to be significant if $\mathrm{p}<0.05$.

\section{RESULTS}

\section{Mussel manipulation}

\section{Sediment nutrient concentration}

Sediment C:N ratios were not significantly different between treatments $(p=0.06)$; however C:P ratios were significantly lower in treatments that contained Modiolus americanus at either density $(\mathrm{p}=0.003$, Fig. 2, Table 1). Sediment C:P ratios were significantly lower in mussel addition treatments from January through September. During this period, sediment C:P ratios for the highest mussel densities were consistently an order of magnitude lower than those in the zero mussel treatments. In addition, the sediment N:P ratio was significantly lower in plots that contained mussels ( $p=0.004$ ). These decreasing nutrient ratios demonstrate that the presence of mussels significantly increased the sediment phosphorus pool. 

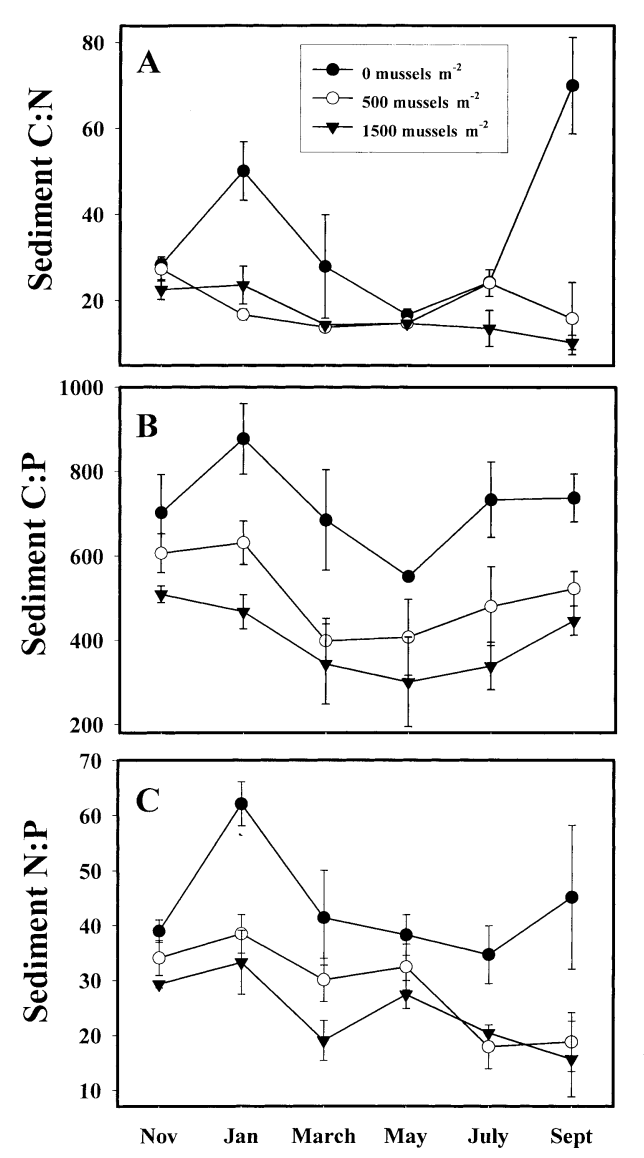

Fig. 2. Effect of manipulation of mussel (Modiolus americanus) density on sediment C:N, C:P and N:P ratios by month (means $\pm 1 \mathrm{SD}$ )

\section{Thalassia testudinum biomass and morphology}

Over the course of the experiment, seagrass aboveground biomass ranged from 76 to $240.9 \mathrm{~g}_{\text {dry }} \mathrm{wt} \mathrm{m}^{-2}$, belowground biomass ranged from 127 to $1171 \mathrm{~g}$ dry wt $\mathrm{m}^{-2}$ and SS densities ranged from 500 to $1500 \mathrm{SS}$ $\mathrm{m}^{-2}$. There were no statistically significant relationships for total above- or belowground biomass or for SS densities among the 3 mussel density levels $(p=0.72$, $p=0.98$ and $p=0.09$, respectively, Table 2 ). Thus, mussel density had no quantitative effects on seagrass biomass. However, the presence of mussels had a significant effect on the leaf morphology of Thalassia testudinum. During the experiment, the mean leaf number $\mathrm{SS}^{-1}$ was significantly affected by mussel density $(p=0.02)$. There were significantly fewer leaves $\mathrm{SS}^{-1}$ in treatments that contained mussels at the beginning of the growing season (Fig. 3A). This trend did not continue. In fact, the trend reversed by September in the highest mussel density treatments. Leaf width was not significantly different between treatments over the course of the experiment $(p=0.06)$. Conversely, leaf
Table 1. Repeated-measures ANOVA table from the mussel (Modiolus americanus) density manipulation experiment for sediment nutrient concentrations

\begin{tabular}{|lrrrrr|}
\hline Source & df & Type III SS & MS & $F$ & $\mathrm{p}>F$ \\
\hline Sediment C:N ratio & & & & & \\
Density & 2 & 0.1548 & 0.0774 & 3.88 & 0.0609 \\
Error (Treatment) & 15 & 0.1795 & 0.0199 & & \\
Time & 3 & 0.1114 & 0.0371 & 3.59 & 0.0265 \\
Time $\times$ Density & 6 & 0.0820 & 0.0137 & 1.32 & 0.2819 \\
Error (Time) & 45 & 0.2793 & 0.0104 & & \\
Total & 62 & & & & \\
Sediment C:P ratio & & & & & \\
Density & 2 & 0.1434 & 0.0717 & 12.43 & 0.0026 \\
Error (Treatment) & 15 & 0.0519 & 0.0058 & & \\
Time & 3 & 0.0474 & 0.0158 & 3.13 & 0.0421 \\
Time $\times$ Density & 6 & 0.0073 & 0.0012 & 0.24 & 0.9591 \\
Error (Time) & 45 & 0.1364 & 0.0051 & & \\
Total & 62 & & & & \\
Sediment N:P ratio & & & & & \\
Density & 2 & 0.2631 & 0.1316 & 10.91 & 0.0039 \\
Error (Treatment) & 15 & 0.1085 & 0.0121 & & \\
Time & 3 & 0.2713 & 0.0904 & 8.11 & 0.0005 \\
Time $\times$ Density & 6 & 0.0805 & 0.0134 & 1.20 & 0.3347 \\
Error (Time) & 45 & 0.3009 & 0.0111 & & \\
Total & 62 & & & & \\
\hline
\end{tabular}

length was significantly different between treatments $(p=0.0001)$. Leaves were longer in the presence of mussels (Fig. 3C). From the initiation of the growing season (May) through July, both treatment plots containing mussels exhibited significantly longer leaves than those in the zero mussel density treatment. In August, however, the intermediate density no longer had an effect on leaf length, while the highest mussel density treatments did.

\section{Leaf tissue $\mathrm{C}: \mathrm{N}, \mathrm{N}: \mathrm{P}$ and $\mathrm{C}: \mathrm{P}$ concentration}

The leaf nutrient content of Thalassia testudinum demonstrated consistent and significant trends between treatments for leaf tissue C:P ratios. Leaves in treatments containing mussels were significantly enriched in phosphorus $(p=0.02)$. There were no significant differences between treatments for leaf tissue $\mathrm{C}: \mathrm{N}$ ratios (Fig. 4A, Table 2). As a result, mussel density significantly decreased leaf tissue N:P ratios (Fig. 4C, Table 2). There was also a significant effect of time on both leaf tissue N:P and C:P ratios (Table 2). Leaf tissue samples collected at the inception of the experiment revealed no significant differences of C:P or N:P between mussel density levels. C:P values decreased from September 1995 to September 1996 in treatments containing mussels. Similarly, N:P values declined for the same treatments. As the growing season continued, N:P values decreased in leaves from plots where mussels were present. 
Table 2. Repeated-measures ANOVA table from the mussel (Modiolus americanus) density manipulation experiment for response variables of Thalassia testudinum

\begin{tabular}{|c|c|c|c|c|c|}
\hline Source & df & Type III SS & MS & $F$ & $\mathrm{p}>F$ \\
\hline \multicolumn{6}{|c|}{ Aboveground biomass } \\
\hline Density & 2 & 3229.99 & 1614.99 & 0.34 & 0.7175 \\
\hline Error (Treatment) & 15 & 42184.49 & 4687.17 & & \\
\hline Time & 4 & 103675.35 & 25918.84 & 6.22 & 0.0054 \\
\hline Time $\times$ Density & 8 & 35333.98 & 4416.75 & 1.06 & 0.4075 \\
\hline Error (Time) & 60 & 150010.59 & 4166.96 & & \\
\hline Total & 89 & & & & \\
\hline \multicolumn{6}{|c|}{ Belowground biomass } \\
\hline Density & 2 & 1719.88 & 859.94 & 0.02 & 0.9817 \\
\hline Error (Treatment) & 15 & 695675.48 & 46378.36 & & \\
\hline Time & 3 & 6465863.72 & 215528.91 & 6.45 & 0.0010 \\
\hline Time $\times$ Density & 6 & 355617.89 & 59269.65 & 1.77 & 0.1263 \\
\hline Error (Time) & 45 & 1504260.24 & 33428.01 & & \\
\hline Total & 81 & & & & \\
\hline \multicolumn{6}{|l|}{ Short-shoot density } \\
\hline Density & 2 & 204814.81 & 102407.41 & 2.73 & 0.0975 \\
\hline Error (Treatment) & 15 & 562777.77 & 37518.52 & & \\
\hline Time & 2 & 413703.73 & 206851.85 & 5.56 & 0.0088 \\
\hline Time $\times$ Density & 4 & 517407.41 & 129351.85 & 3.48 & 0.0189 \\
\hline Error (Time) & 30 & 1115555.56 & 37185.19 & & \\
\hline Total & 53 & & & & \\
\hline \multicolumn{6}{|l|}{ Leaf number } \\
\hline Density & 2 & 7.0317 & 3.5159 & 3.97 & 0.0214 \\
\hline Error (Treatment) & 120 & 106.3341 & 0.8861 & & \\
\hline Time & 4 & 77.7069 & 19.4267 & 21.78 & 0.0001 \\
\hline Time $\times$ Density & 8 & 22.0722 & 2.7590 & 3.09 & 0.0037 \\
\hline Error (Time) & 480 & 428.0579 & 0.8918 & & \\
\hline Total & 614 & & & & \\
\hline \multicolumn{6}{|l|}{ Leaf width } \\
\hline Density & 2 & 6.9466 & 3.4733 & 2.81 & 0.0616 \\
\hline Error (Treatment) & 375 & 463.9144 & 1.2371 & & \\
\hline Time & 4 & 53.2757 & 13.3189 & 11.62 & 0.0001 \\
\hline Time $\times$ Density & 8 & 74.8715 & 9.3589 & 8.16 & 0.0001 \\
\hline Error (Time) & 1500 & 1719.8396 & 1.1466 & & \\
\hline Total & 1889 & & & & \\
\hline \multicolumn{6}{|l|}{ Leaf length } \\
\hline Density & 2 & 287409.18 & 143704.59 & 12.04 & 0.0001 \\
\hline Error (Treatment) & 381 & 4546385.58 & 11932.77 & & \\
\hline Time & 4 & 2722896.12 & 680724.03 & 74.90 & 0.0001 \\
\hline Time $\times$ Density & 8 & 211740.34 & 26467.54 & 2.91 & 0.0032 \\
\hline Error (Time) & 1524 & 13850677.34 & 9088.37 & & \\
\hline Total & 1919 & & & & \\
\hline \multicolumn{6}{|c|}{ Leaf tissue $\mathrm{C}: \mathrm{N}$ ratio } \\
\hline Density & 2 & 0.0331 & 0.0165 & 1.62 & 0.2740 \\
\hline Error (Treatment) & 15 & 0.0613 & 0.0102 & & \\
\hline Time & 2 & 0.3067 & 0.1533 & 17.97 & 0.0005 \\
\hline Time $\times$ Density & 4 & 0.0732 & 0.0183 & 2.15 & 0.1502 \\
\hline Error (Time) & 30 & 0.1024 & 0.0008 & & \\
\hline Total & 53 & & & & \\
\hline \multicolumn{6}{|l|}{ Leaf tissue $\mathrm{C}: \mathrm{P}$ ratio } \\
\hline Density & 2 & 0.0102 & 0.0151 & 6.02 & 0.0213 \\
\hline Error (Treatment) & 15 & 0.0151 & 0.0025 & & \\
\hline Time & 2 & 0.0433 & 0.0217 & 12.49 & 0.0012 \\
\hline Time $\times$ Density & 4 & 0.0099 & 0.0025 & 1.43 & 0.2821 \\
\hline Error (Time) & 30 & 0.0208 & 0.0017 & & \\
\hline Total & 53 & & & & \\
\hline \multicolumn{6}{|c|}{ Leaf tissue N:P ratio } \\
\hline Density & 2 & 0.0297 & 0.0149 & 14.69 & 0.0049 \\
\hline Error (Treatment) & 15 & 0.0061 & 0.0010 & & \\
\hline Time & 2 & 0.1180 & 0.0590 & 70.03 & 0.0001 \\
\hline Time $\times$ Density & 4 & 0.0465 & 0.0116 & 13.80 & 0.0002 \\
\hline Error (Time) & 30 & 0.0101 & 0.0008 & & \\
\hline Total & 53 & & & & \\
\hline \multicolumn{6}{|c|}{ Thalassia productivity } \\
\hline Density & 2 & 30.7442 & 15.3721 & 14.24 & 0.0016 \\
\hline Error (Treatment) & 15 & 9.7121 & 1.0791 & & \\
\hline Time & 2 & 3.8011 & 0.9503 & 1.37 & 0.2701 \\
\hline Time $\times$ Density & 4 & 9.3481 & 1.1685 & 1.69 & 0.1535 \\
\hline Error (Time) & 60 & 24.9646 & 0.6935 & & \\
\hline
\end{tabular}
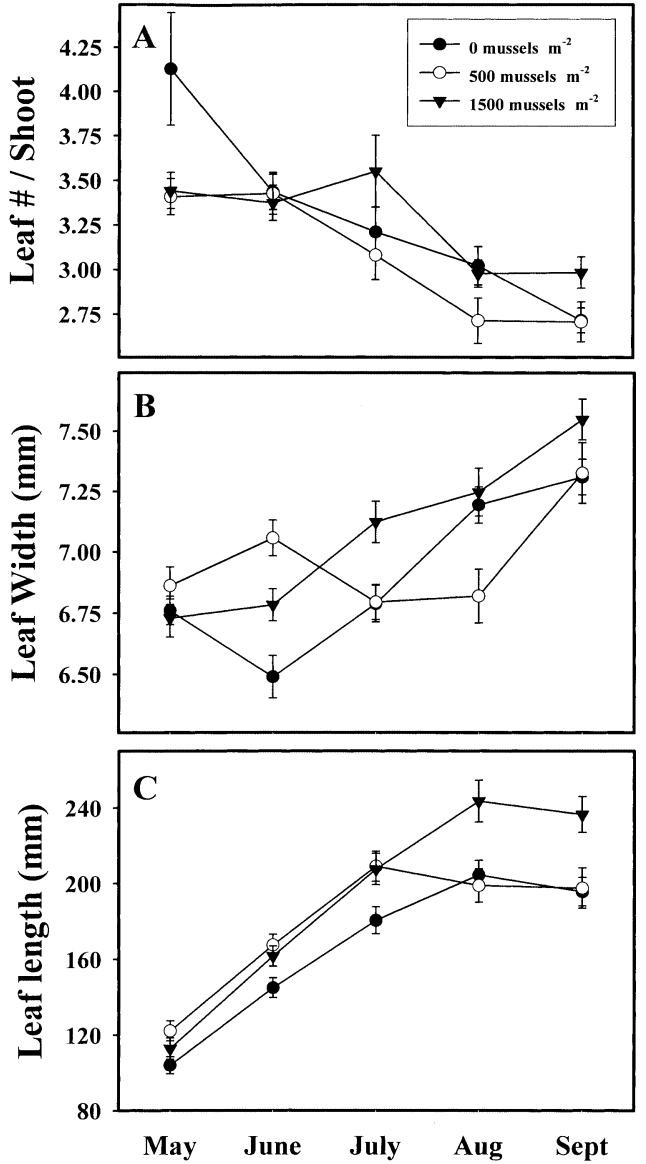

Fig. 3. Effect of manipulation of mussel (Modiolus americanus) density on leaf number per shoot, leaf width and leaf length by month (means $\pm 1 \mathrm{SD}$ )

\section{Primary production}

Mussel density had a significant effect on Thalassia testudinum production $(\mathrm{p}=0.002)$. Net aboveground primary production (NAPP) increased with increasing mussel density in all months (Fig. 5, Table 2). In June and August, both mussel densities (500 and 1500 mussels $\mathrm{m}^{-2}$ ) resulted in significantly greater levels of seagrass productivity than the 0 mussels $\mathrm{m}^{-2}$ density level. During the early portion of the growing season (May and June), the effect of mussels on T. testudinum productivity was similar for both mussel densities. However, from June through September, the highest mussel density level produced the greatest positive response in $T$. testudinum productivity. While NAPP ranged from 2.42 to $5.16 \mathrm{~g}$ dry wt $\mathrm{m}^{-2} \mathrm{~d}^{-1}$ over the entire growing season for the 0 mussels $\mathrm{m}^{-2}$ density treatment, it ranged from 2.63 to $7.38 \mathrm{~g}$ dry wt $\mathrm{m}^{-2} \mathrm{~d}^{-1}$ for the 500 mussels $\mathrm{m}^{-2}$ and from 3.29 to $6.63 \mathrm{~g}$ dry wt $\mathrm{m}^{-2} \mathrm{~d}^{-1}$ for the 1500 mussels $\mathrm{m}^{-2}$ treatments. During the months of May and June, where mussels were pre- 

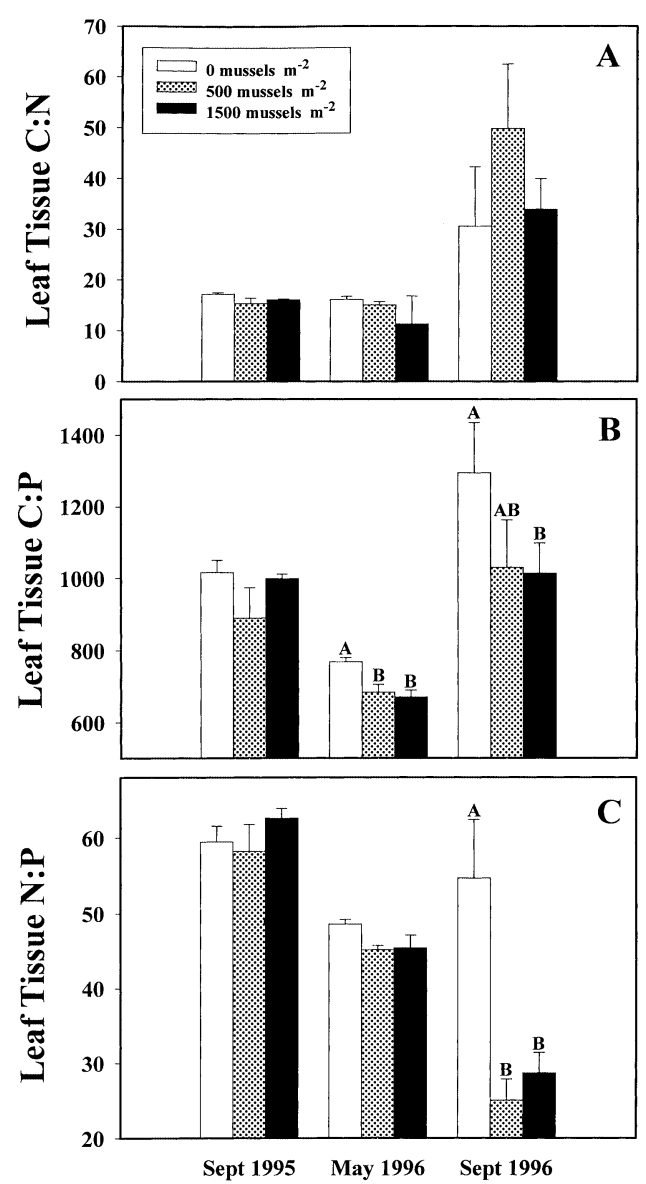

Fig. 4. Effect of manipulation of mussel (Modiolus americanus) density on leaf tissue, C:N, C:P and N:P ratios (means +1 SD). Differing letters indicate significant differences between treatments (Tukey's Studentized range multiple-comparison method)

sent, the productivity of $T$. testudinum approximately doubled that of the 0 mussels $\mathrm{m}^{-2}$ density treatment (Fig. 5). This trend continued for the highest mussel density throughout the experiment.

\section{Epiphytic biomass}

Over the entire experiment, the epiphytic biomass was consistently lower in the presence of mussels ( $p=0.0001$ ) (Fig. 6A, Table 3). Thalassia testudinum leaves at both the 500 and 1500 mussels $\mathrm{m}^{-2}$ density levels possessed significantly lower epiphytic loads than those in the 0 mussels $\mathrm{m}^{-2}$ treatment in every month sampled except May. During the growing season, epiphytic loads increased in all treatments, although by September epiphytic loads in both the 500 and 1500 mussels $\mathrm{m}^{-2}$ levels were less than half those present in the 0 mussels $\mathrm{m}^{-2}$ treatments. This shows that there was a significant reduction in epi-

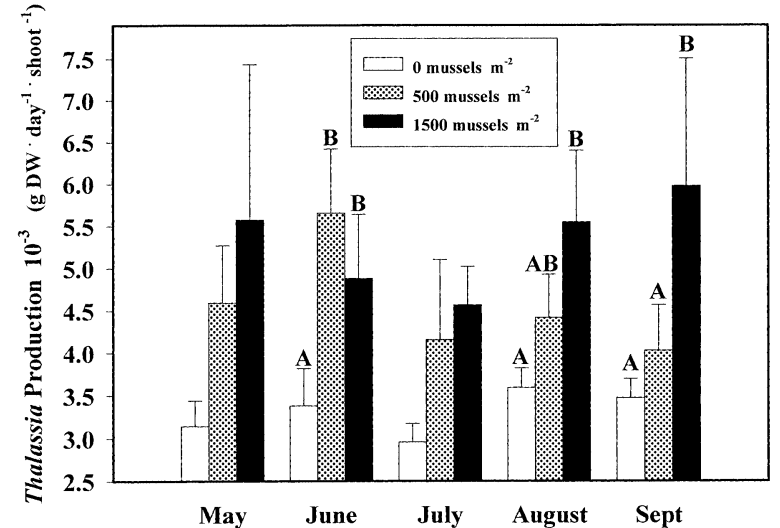

Fig. 5. Effect of manipulation of mussel (Modiolus americanus) density on Thalassia testudinum production (means $+1 \mathrm{SD}$ ). Differing letters indicate significant differences between treatments (Tukey's Studentized range multiple-comparison method). DW: dry weight
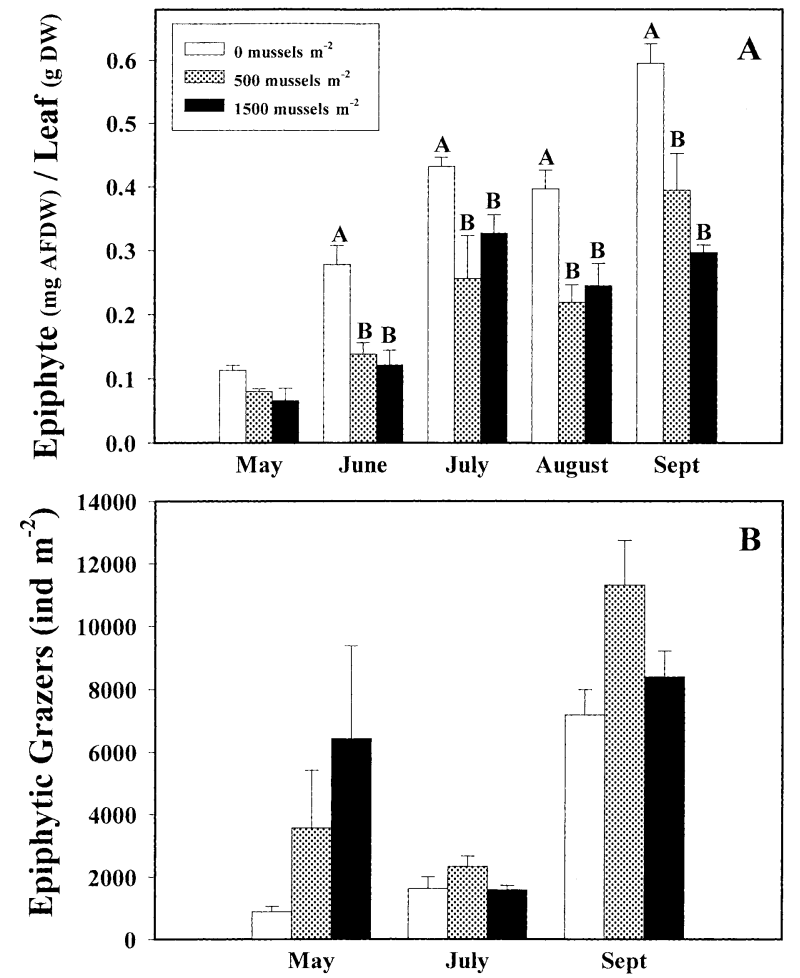

Fig. 6. Effect of manipulation of mussel (Modiolus americanus) density on epiphytic biomass and epiphytic grazer densities (means +1 SD). Differing letters indicate significant differences between treatments (Tukey's Studentized range multiplecomparison method). AFDW: ash-free dry weight

phytic biomass on the leaves of $T$. testudinum when mussels were present.

Repeated-measures ANOVA revealed no significant effects of mussel density on epiphytic grazer densities $(p=0.16)$ (Fig. 6B, Table 3). Early in the 
Table 3. Repeated-measures ANOVA table from the mussel (Modiolus americanus) density manipulation experiment for epiphytic grazer densities and epiphyte biomass

\begin{tabular}{|c|c|c|c|c|c|}
\hline Source & df & Type III SS & MS & $F$ & $\mathrm{p}>F$ \\
\hline \multicolumn{6}{|l|}{ Epiphyte biomass } \\
\hline Density & 2 & 0.1723 & 0.0862 & 38.76 & 0.0001 \\
\hline Error (Treatment) & 15 & 0.0200 & 0.0022 & & \\
\hline Time & 2 & 0.8482 & 0.2120 & 56.62 & 0.0001 \\
\hline Time $\times$ Density & 8 & 0.0505 & 0.0063 & 1.69 & 0.1356 \\
\hline Error (Time) & 60 & 0.1348 & 0.0037 & & \\
\hline Total & 89 & & & & \\
\hline \multicolumn{6}{|c|}{ Ephiphytic grazer densities } \\
\hline Density & 2 & 45222633.59 & 22611316.79 & 2.30 & 0.1565 \\
\hline Error (Treatment) & 15 & 88658022.90 & 9850891.43 & & \\
\hline Time & 2 & 328436466.37 & 164218233.13 & 29.51 & 0.0001 \\
\hline Time $\times$ Density & 4 & 53494404.78 & 13373601.20 & 2.40 & 0.0878 \\
\hline Error (Time) & 30 & 100159492.07 & 5564416.23 & & \\
\hline Total & 53 & & & & \\
\hline
\end{tabular}

growing season there was a slight positive response by epiphytic grazer densities to increasing mussel densities (Fig. 6B), but there was no clear trend between the treatment levels during the month of July. In September, there again appeared to be greater epiphytic grazer densities in both the 500 and 1500 mussels $\mathrm{m}^{-2}$ density levels, but no statistically significant differences. A list of the epiphytic grazer organisms present in the treatments is provided in Table 4. Separating the grazers into distinct phylogenetic groups revealed no significant differences between treatments.

\section{Test of Thalassia testudinum as a predation refuge}

Average aboveground biomass in the Thalassia testudinum experimental seagrass meadows was $219.14 \mathrm{~g}$ dry wt (130.91 g AFDW), with SS densities averaging $1300 \mathrm{SS} \mathrm{m}^{-2}$. Average belowground biomass in both $T$. testudinum natural and T. testudinum clipped experimental areas was $495.06 \mathrm{~g}$ dry wt (147.12 g AFDW). Although predation was not directly observed in this experiment, dead mussels in each plot could be identified by their individual marking number on the shell fragments, demonstrating that these individuals did not emigrate out of the plot. All dead shells were found crushed. Mean survival was significantly different among the 3 habitats $(F=129.47$, df $=29$, p < 0.001); significantly greater mortality occurred on the sand bottom than in either seagrass treatment (Fig. 7). There was no significant difference, however, in the number of surviving individuals between the 2 vegetated habitats. This experiment demonstrated that those mussels associated with the seagrass had higher survival rates than those that occupied unvegetated sediments.
Table 4. Family and species list (when determined) of potential epiphytic grazers found in suction samples collected in St. Joseph Bay, Florida

\begin{tabular}{|c|c|}
\hline Phylum, Family & Species \\
\hline \multicolumn{2}{|l|}{ Mollusca } \\
\hline Trochidae & Calliostoma sp. \\
\hline Turbinidae & Turbo castaneus \\
\hline \multirow[t]{5}{*}{ Cerithiidae } & Cerithiopsis emersoni \\
\hline & Cerithium atratum \\
\hline & Cerithium ebureum \\
\hline & Cerithium muscarum \\
\hline & Diastoma varium \\
\hline Modulidae & Modulus modulus \\
\hline Rissoidae & Rissoina bryerea \\
\hline Columbellidae & $\begin{array}{l}\text { Zebina browniana } \\
\text { Mitrella lunata } \\
\text { Mitrella ocellata }\end{array}$ \\
\hline Callistoplacidae & Ceratozona squalida \\
\hline Chitonidae & Chiton squamosus \\
\hline Ischnochitonidae & $\begin{array}{l}\text { Chaetopleura apiculata } \\
\text { Ischnochiton papillosus }\end{array}$ \\
\hline \multicolumn{2}{|l|}{ Arthropoda } \\
\hline Idoteidae & $\begin{array}{l}\text { Erichsonella sp. } \\
\text { Idotea sp. }\end{array}$ \\
\hline \multicolumn{2}{|l|}{ Sphaeromidae } \\
\hline \multicolumn{2}{|l|}{ Anthuridae } \\
\hline \multicolumn{2}{|l|}{ Asellota } \\
\hline Amphithoidae & Cymadusa sp. \\
\hline \multicolumn{2}{|l|}{ Aoridae } \\
\hline \multicolumn{2}{|l|}{ Eusiridae } \\
\hline \multicolumn{2}{|l|}{ Melitidae } \\
\hline \multicolumn{2}{|l|}{ Hyalidae } \\
\hline \multicolumn{2}{|l|}{ Leucothoidae } \\
\hline \multicolumn{2}{|l|}{ Lilljeborgiidae } \\
\hline \multicolumn{2}{|l|}{ Oedicerotidae } \\
\hline \multicolumn{2}{|l|}{ Photidae } \\
\hline \multicolumn{2}{|l|}{ Phoxocephalidae } \\
\hline \multicolumn{2}{|l|}{ Pleustidae } \\
\hline Caprellidae & $\begin{array}{l}\text { Deutella sp. } \\
\text { Paracaprella sp. }\end{array}$ \\
\hline \multicolumn{2}{|l|}{ Penaeidea } \\
\hline \multicolumn{2}{|l|}{ Caridea } \\
\hline Hippolytidae & Tozeuma sp. \\
\hline Paguridae & Pagurus sp. \\
\hline Diogenidae & Paguristes sp. \\
\hline Porcellanidae & \\
\hline Majidae & \\
\hline
\end{tabular}

\section{DISCUSSION}

\section{Effect of mussels on the seagrass community}

The focus of this study was to determine the role suspension-feeding mussels Modiolus americanus had in seagrass Thalassia testudinum meadows. Suspensionfeeding mussels produce 3 major effects on seagrass communities: (1) changes in sediment and plant nutrient levels; (2) changes in plant morphology and productivity; and (3) changes in epiphytic load on the leaves. In this study, mussel additions significantly 


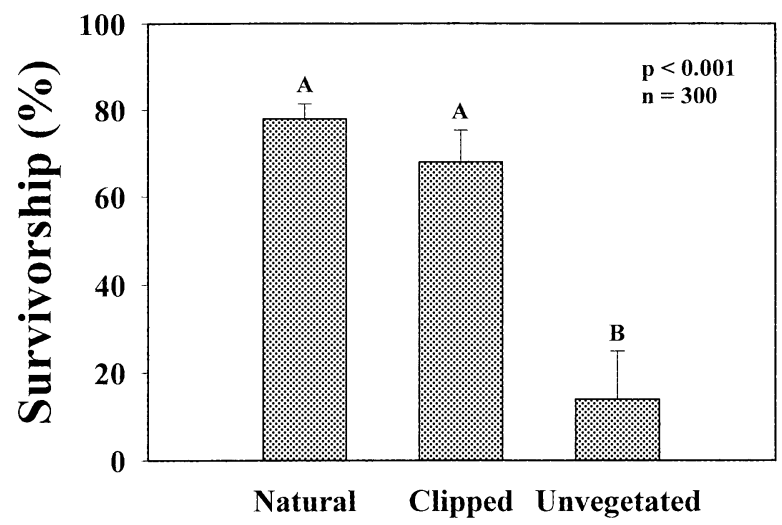

Fig. 7. Percentage survivorship of Modiolus americanus in natural Thalassia testudinum area, in clipped T. testudinum area, and in unvegetated sand area (means $+1 \mathrm{SD}$ ). Differing letters indicate significant differences between treatments (Tukey's Studentized range multiple-comparison method)

increased the amount of total $\mathrm{N}$ and $\mathrm{P}$ in the sediments. In addition to the increase in sediment nutrient concentration, the presence of mussels altered leaf tissue $\mathrm{N}: \mathrm{P}$ and $\mathrm{C}: \mathrm{P}$ ratios. In previous studies, the $\mathrm{C}: \mathrm{N}$ and $\mathrm{C}: \mathrm{P}$ ratios of plants have been used to assess the nutrient status of phytoplankton (Redfield 1958) and macrophytes (Gerloff \& Krombholtz 1966). The amount of N or $\mathrm{P}$ (relative to carbon) in plant tissues is a function of the availability of $\mathrm{N}$ or $\mathrm{P}$ in the environment. Fourqurean et al. (1992b) found that the leaf tissue C:N and C:P of Thalassia testudinum decreased with increasing pore-water soluble reactive phosphorus and ammonium. Furthermore, the N:P ratio of seagrass leaf tissue reflected the relative availability of $\mathrm{N}$ and $\mathrm{P}$ in the environment. Analysis of plant tissue from the mussel manipulations revealed significant effects of mussels on total phosphate in the leaf tissue. Thus, $T$. testudinum leaves in the presence of mussels are enriched with phosphate, indicating that the increased nutrient concentration of the sediments is biologically available to the plant. There are 3 potential effects that mussels may have on seagrass communities. By adding phosphate to the sediments, Short et al. (1990) observed significantly increased growth and increased rates of rhizosphere $\mathrm{N}$-fixation. The increase in $\mathrm{N}$-fixation was of the same magnitude as the P enrichments. Although the effect of mussels on N-fixation was not addressed in this study, the study by Short et al. suggests that Modiolus americanus may create microzones of increased $\mathrm{N}$-fixation as a result of the $\mathrm{P}$ enrichment. Another potentially important impact of mussels on seagrass communities is the possible high sulfate reduction which may occur in the organically rich sediments (Capone \& Kiene 1988) associated with aggregates of $M$. americanus or other suspension-feeders. High sulfate reduction could lead to a decrease in iron oxides in the sediments (Carriganan \& Tessier
1988) and a decrease in $\mathrm{P}$ sorption (Schindler et al. 1985, Caraco et al. 1989). Phosphate has been clearly demonstrated as the primary factor limiting the growth of seagrasses in tropical carbonate environments (Short et al. 1990, Fourqurean 1992a). The substantial increase in seagrass productivity and leaf tissue $\mathrm{P}$ content in the live mussel treatments shows alleviation of $\mathrm{P}$ limitation and implies a shift to $\mathrm{N}$ limitation. However, severe $\mathrm{N}$ limitation may be hypothesized to be mitigated by increased $\mathrm{N}$-fixation associated with $M$. americanus aggregations.

In addition to increasing the nutrient levels of the sediments and the plants, the presence of mussels significantly affected plant morphology; specifically, leaf lengths increased. Thus, the plants produced significantly greater photosynthetically active tissue in areas where mussels were present. Intuitively, this would have a profound impact on the productivity of Thalassia testudinum by increasing the plant's ability to absorb light. Furthermore, the possession of wider, taller leaves may also have important implications for intraand interspecific light competition, locally increased sedimentation rates and increased plant refuge potential. In conjunction with changes in plant morphology, productivity of $T$. testudinum was significantly altered by the presence of Modiolus americanus. Increased rates of productivity were measured for every month of the growing season in mussel addition treatments. These rates of productivity reached levels twice those of the 0 mussels $\mathrm{m}^{-2}$ density. The experimental design was insufficient to address which factor, either increased nutrient levels or increased photosynthetically active tissue, is responsible for the increase in productivity. Regardless, the plants responded to the presence of mussels by increasing blade length and grew at an elevated rate.

The final major effect of the mussel additions on Thalassia testudinum was a change in leaf epiphytic loads. Epiphytic biomass was significantly reduced in the presence of Modiolus americanus. This effect increased as the growing season proceeded. The role of epiphytes in attenuation of light has been well demonstrated (for review see Orth \& van Montfrans 1984, Neckles et al. 1993), suggesting that a reduction in epiphytic biomass would correspond to an increase in light absorption by $T$. testudinum associated with $M$. americanus. The percentage light reduction attributed to the presence of epiphytic loads on the seagrass leaves was calculated using an equation from Fong \& Harwell (1994). For June and August, the highest mussel densities resulted in approximately $10 \%$ less light reduction than in the 0 mussel density treatments.

Quantitative suction sampling of the mussel density manipulation experiment revealed no significant increase in numbers of epiphytic grazers with the pres- 
ence of Modiolus americanus. This was unexpected, given the reduced epiphytic loads on the leaves. Several possible explanations for the reduction in epiphyte biomass can be given. Epiphytic grazers not collected with the suction sampling may be responsible; for instance, many of the epiphytic grazers are highly motile. Perhaps the quantity of epiphytic grazers remains the same in each treatment, but in association with $M$. americanus and the potential refuge these mussels provide, they spend a greater proportion of time grazing the leaves. Alternatively, the mussels themselves may potentially reduce epiphytic loads by consuming the epiphyte propagules before recruitment to the leaves. Lastly, elevated productivity of the plant may cause the reduced epiphytic loads. If the leaves are growing at an elevated rate, epiphytes have less time to accumulate on the leaves. Regardless of which mechanism is responsible, Thalassia testudinum leaves associated with mussels have significantly reduced epiphytic loads. This allows the plants to obtain up to $10 \%$ more light when mussels are present.

Previous studies have shown that nutrient enrichment and epiphytic loads both exert strong individual controls on the production of seagrass. This experiment demonstrated that both mechanisms occur in the presence of Modiolus americanus, which may have a significant impact on the seagrass bed mosaic of nutrient availability and productivity. $M$. americanus aggregates can be envisioned as productivity 'hot spots' within the bed. Enhanced productivity at the beginning of the growing season and prolonged productivity at the end may have dramatic effects on the 'fitness' of a seagrass clone.

\section{Is there a mutualistic relationship between Modiolus americanus and Thalassia testudinum?}

The purpose of the second experiment was to examine the reciprocal role of Thalassia testudinum on Modiolus americanus. Because many previous studies have demonstrated that the survival rates of infaunal bivalves are significantly greater within seagrass assemblages than in unvegetated soft sediments (Blundon \& Kennedy 1982, Peterson 1982, 1986, Coen \& Heck 1991), the results of this study were not unexpected. This experiment, while confirming previous investigations of the role of submerged aquatic vegetation on increasing survival rates of infaunal bivalves in general, extends these observations to $M$. americanus in particular.

Mutualistic associations vary along a great continuum from tight, obligate associations to diffuse, facultative associations. The majority of previous research has focused on the tight, obligate end of the spectrum because these associations are the most apparent. However, possibly the most prevalent mutualisms in natural communities (and perhaps the least understood) are the facultative associations. Bertness (1984, 1985) described 2 interesting facultative mutualisms between fiddler crabs and ribbed mussels with the marsh plant Spartina alterniflora. He found that at the marsh edge, sediments were stabilized by the roots, rhizomes and debris of $S$. alterniflora. The marsh grass provided suitable sediment stability for fiddler crab burrowing activity, which consequently increased aboveground $S$. alterniflora production and prevented a dense root mat establishment. In addition, the biodeposition of the ribbed mussels had a significant effect on productivity of $S$. alterniflora beds.

Similarly, this study illustrates that seagrass assemblages significantly affect the survival of a suspensionfeeding bivalve. Therefore, the random association of these 2 organisms results in elevated leaf-tissue nutrient content, increased photosynthetic tissue, elevated productivity of Thalassia testudinum and increased survivorship of Modiolus americanus. While the evidence for a facultative mutualism is strong between these 2 organisms, the mechanism for this mutualistic relationship is quite broad. The role of suspensionfeeders in general among seagrass assemblages may be similar to that of $M$. americanus.

\section{Ecological significance}

Early ecologists recognized that both positive and negative interactions among species were important driving forces in the structure of communities (Clements et al. 1926, Allee et al. 1949). While this perspective has been discarded from modern ecology for the most part, a re-examination of the role of positive interactions in community development has recently begun (Bertness \& Callaway 1994, Bertness \& Leonard 1997, Callaway \& Walker 1997, Hacker \& Gaines 1997, Holmgren et al. 1997, Jones et al. 1997). Although few contemporary ecologists would deny the presence of positive interactions in natural communities, the general importance of positive interactions to community diversity, structure and productivity is rarely acknowledged. In the past, primary and secondary succession were thought to be driven by facilitative and positive interactions. Recently Bertness' (Bertness 1992, Bertness \& Shumway 1993) work with marine vascular plant communities has illustrated the importance of positive interactions during succession. Facilitative succession has also been demonstrated previously in seagrass beds. In rocky intertidal habitats, Turner (1983) found that the recruitment of surfgrass Phyllospadix scouleri seeds into experimental plots was significantly in- 
creased by the presence of the red algae Rhodomela larix and Odonthalia floccosa. Seagrass colonization of sandy substrate is limited by low sediment nutrient levels, which can be ameliorated by algal neighbors (Williams 1980). Consequently, seagrass colonization is facilitated by the presence of algae in low-nutrient substrates. A similar facilitative role of increasing sediment nutrient levels can be envisioned for mussels in seagrass communities.

This study identifies 2 beneficial effects of Modiolus americanus on seagrasses that may affect seagrass community development (Fig. 8). First, M. americanus was found to influence sediment nutrient content. Aggregates of $M$. americanus significantly increased the pool of $\mathrm{N}$ and $\mathrm{P}$ available to Thalassia testudinum. The dramatic increase in $\mathrm{P}$ may have a more significant impact on seagrasses in the Gulf of Mexico and Caribbean Sea, where carbonate sediments often dominate nearshore environments. Second, the epiphytic biomass on the leaves of $T$. testudinum is significantly altered by the presence of $M$. americanus. This may be particularly important in areas experiencing increased levels of eutrophication. Hence, M. americanus patches may serve as nutrient and productivity 'hot spots' within seagrass communities.

Modern community ecology has underestimated the role of positive interactions by largely ignoring the community consequences of potential positive feedback mechanisms between organisms and their environment. The recent conceptual model of the occurrence of positive interaction in natural communities by Bertness \& Callaway (1994) predicts that in habitats where there is low consumer pressure and high physical stress there will be a high frequency of positive interactions and, furthermore, that these positive interactions will constitute a neighborhood habitat-amelio-

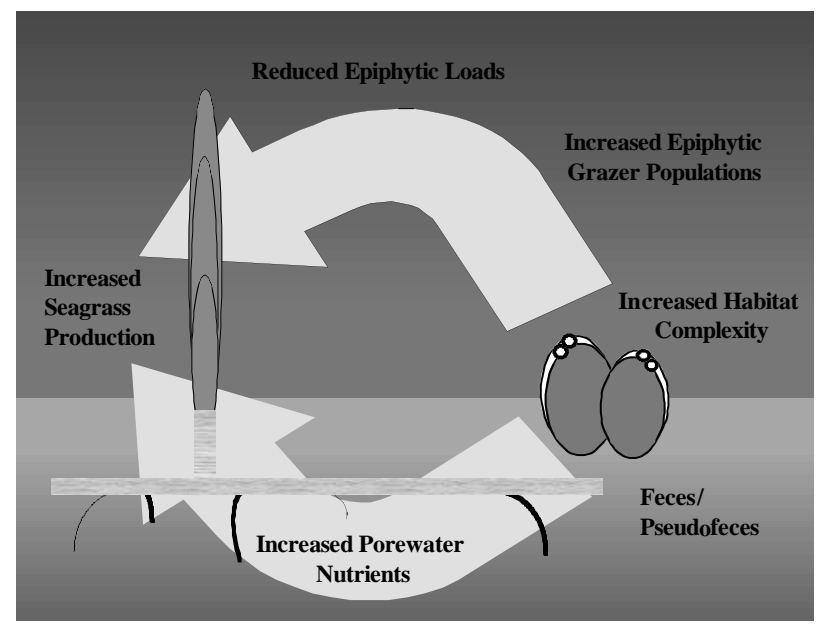

Fig. 8. Conceptual model of the role of Modiolus americanus in Thalassia testudinum productivity ration mechanism. This model accurately predicts the positive interactions demonstrated in this study. Spatial and temporal variability in the presence of seagrass has most frequently been attributed to the changes in the availability of nutrients and light. In this study, the presence of 1 particular organism significantly changed the availability of both parameters, nutrients and light, to Thalassia testudinum. The impact of this organism, Modiolus americanus, on seagrass community structure and development is potentially great. Modern community ecology would benefit from a concerted reexamination of the role of positive interactions in the development, structure and organization of natural communities.

Acknowledgements. The authors would like to thank Brenda Peterson, Barbara Flom, Kimbrough Ferrell, Susan Sklenar, Katherine Canter, Trisha Spitzer, Paul Bologna and Jean Coawan for field and laboratory assistance. This paper has been substantially improved via many discussions and helpful comments from John Valentine, Jim Cowan and Mark Bertness. Funding for this project was provided in part by the Mississippi-Alabama Sea Grant, University of South Alabama, and the Dauphin Island Sea Laboratory. We thank the Dauphin Island Sea Laboratory faculty and staff for their help in all phases of this project. This is contribution no. 329 of the Dauphin Island Sea Laboratory and contribution no. 143 of the Southeast Environmental Research Center.

\section{LITERATURE CITED}

Allee WC, Emerson AE, Park O, Park T, Schmidt KP (1949) Principles of animal ecology. Saunders, Philadelphia

Andrews J (1977) Shells and shores of Texas. University of Texas Press, Austin

Bertness MD (1984) Ribbed mussels and Spartina alterniflora production in a New England salt marsh. Ecology 65: 1794-1807

Bertness MD (1985) Fiddler crab regulation of Spartina alterniflora production on a New England salt marsh. Ecology 66:1042-1055

Bertness MD (1992) The ecology of a New England salt marsh. Am Sci 80:260-268

Bertness MD, Callaway R (1994) Positive interactions in communities: a post cold war perspective. Trends Ecol Evol 9: 191-193

Bertness MD, Leonard GH (1997) The role of positive interactions in communities: lessons from intertidal habitats. Ecology 78:1976-1989

Bertness MD, Shumway SW (1993) Competition and facilitation in marsh plants. Am Sci 142:718-724

Blundon JA, Kennedy VS (1982) Refuges for infaunal bivalves from blue crab, Callinectes sapidum (Rathbun), predation in Chesapeake Bay. J Exp Mar Biol Ecol 65:67-81

Callaway RM, Walker LR (1997) Competition and facilitation: a synthetic approach to interactions in plant communities. Ecology 78:1958-1965

Capone DG, Kiene RP (1988) Comparison of microbial dynamics in marine and freshwater sediments - contrasts in anaerobic carbon catabolism - review. Limnol Oceanogr $33: 725-749$ 
Caraco R, Cole J J, Likens GE (1989) Evidence for sulfate controlled phosphorus release from sediments of aquatic systems. Nature 341:316-318

Carrigan R, Tessier A (1988) The CO-diagenesis of sulfur and iron in acid lake sediments of southwestern Quebec. Geochim Cosmochim Acta 52:1179-1188

Clements FE, Weaver JE, Hanson HC (1926) Plant competition: an analysis of the development of vegetation. Carnegie Institute, Washington, DC

Coen LD, Heck KL Jr (1991) The interacting effects of siphon nipping and habitat on bivalve (Mercenaria mercenaria (L.)) growth in a subtropical seagrass (Halodule wrightii Aschers.) meadow. J Exp Mar Biol Ecol 145:1-13

Dame RF, Dankers N (1988) Uptake and release of materials by a Wadden Sea mussel bed. J Exp Mar Biol Ecol 118:207-216

Dame RF, Zingmark R, Stevenson H, Nelson D (1980) Filter feeding coupling between the estuarine water column and benthic subsystems. In: Kennedy VS (ed) Estuarine perspectives. Academic Press, New York, p 521-526

Dame RF, Zingmark RG, Haskin E (1984) Oyster reefs as processors of estuarine materials. J Exp Mar Biol Ecol 83: 239-247

Dame RF, Wolaver TG, Libes SM (1985) The summer uptake and release of nitrogen by an intertidal oyster reef. Neth J Sea Res 19:265-268

Dame RF, Spurrier JD, Wolaver TG (1989) Carbon, nitrogen, and phosphorus processing by an oyster reef. Mar Ecol Prog Ser 54:249-256

Folger DW (1972) Characteristics of estuarine sediments of the United States. Prof Pap US Geol Surv 742:1-95

Fong P, Harwell MA (1994) Modeling seagrass communities in tropical and subtropical bays and estuaries: a mathematical model synthesis of current hypothesis. Bull Mar Sci 54:757-781

Fourqurean JW, Zieman JC, Powell GVN (1992a) Relationships between porewater nutrients and seagrasses in a subtropical carbonate environment. Mar Biol 114:57-65

Fourqurean JW, Zieman JC, Powell GVN (1992b) Phosphorus limitation of primary production in Florida Bay: evidence from C:N:P ratios of the dominant seagrass. Limnol Oceanogr 37:162-171

Frechette M, Bourget E (1985) Energy flow between the pelagic and benthic zones: factors controlling particulate organic matter available to an intertidal mussel bed. Can J Fish Aquat Sci 42:1158-1165

Gerloff GC, Krombholtz PH (1966) Tissue analysis as a measure of nutrient availability for the growth of angiosperm aquatic plants. Limnol Oceanogr 11:529-537

Hacker SD, Gaines SD (1997) Some implications of direct positive interactions for community species diversity. Ecology 78:1990-2003

Holm NG (1978) Phosphorus exchange through the sedimentwater interface: mechanism studies of dynamic processes in the Baltic Sea. In: Microbial geochemistry. Department of Geology, University of Stockholm

Holmgren M, Scheffer M, Huston MA (1997) The interplay of facilitation and competition in plant communities. Ecology 78:1966-1975

Iverson RL, Bittaker HF (1986) Seagrass distribution and abundance in the eastern Gulf of Mexico waters. Estuar Coast Shelf Sci 22:577-602

Jackson JBC (1973) The ecology of molluscs of Thalassia communities, Jamaica, West Indies. I. Distribution, environmental physiology, and ecology of common shallow-water species. Bull Mar Sci 23:313-350

Jansson BO, Wulff F (1977) Ecosystem analysis of a shallow sound in the Northern Baltic - a joint study by the Asko
Group. University of Stockholm, Stockholm

Jones CG, Lawton JH, Shachak M (1997) Positive and negative effects of organisms as physical ecosystem engineers. Ecology 78:1946-1957

Jordan JE, Valiela I (1982) A nitrogen budget of the ribbed mussel, Geukensia demissa, and its significance to nitrogen flow in a New England salt marsh. Limnol Oceanogr 27:75-90

Jørgensen CB (1990) Bivalve filter feeding: hydrodynamics, bioenergetics, physiology and ecology. Olsen \& Olsen, Fredensberg

Kautsky N, Evans S (1987) Role of biodeposition by Mytilus edulis in the circulation of matter and nutrients in a Baltic coastal ecosystem. Mar Ecol Prog Ser 38:201-212

Lyons WG (1989) Nearshore marine ecology at Hutchinson Island, Florida: 1971-1974. XI. Mollusks. Fla Mar Res Publ 47:1-131

McNulty JK, Lindahl WC, Sykes JE (1972) Cooperative Gulf of Mexico estuarine inventory and study, Florida: phase I, area description. NOAA Tech Rep NMFS 368:1-368

Neckles HA, Wetzel RL, Orth RJ (1993) Relative effects of nutrient enrichment and grazing on epiphyte-macrophyte (Zostera marina L.) dynamics. Oecologia 93:285-295

Nixon SW, Kelly JR, Furnas BN, Oviatt CA, Hale SS (1980) Phosphorus regeneration and the metabolism of coastal marine bottom communities. In: Tenore KR, Coull BC (eds) Marine benthic dynamics. University of South Carolina Press, Columbia, p 219-242

Orth RJ, van Montfrans J (1984) Epiphyte-seagrass relationships with an emphasis on the role of micrograzing: a review. Aquat Bot 18:43-69

Peterson CH (1982) Clam predation by whelks (Busycon spp.): experimental tests of the importance of prey size, prey density, and seagrass cover. Mar Biol 66:159-170

Peterson CH (1986) Enhancement of Mercenaria mercenaria densities in seagrass beds: is pattern fixed during settlement season or altered by subsequent differential survival? Limnol Oceanogr 31:200-205

Redfield AC (1958) The biological control of chemical factors in the environment. Am Sci 46:561-600

Reusch TBH, Williams SL (1998) Variable responses of native eelgrass Zostera marina to a non-indigenous bivalve Musculista senhousia. Oecologia 113:428-442

Reusch TBH, Chapman ARO, Gröger JP (1994) Blue mussels Mytilus edulis do not interfere with eelgrass Zostera marina but fertilize shoot growth through biodeposition. Mar Ecol Prog Ser 108:265-282

Rodriguez G (1959) The marine communities of Margarita Island, Venezuela. Bull Mar Sci Gulf Caribb 9:237-280

Rudloe A (1985) Variation in the expression of lunar and tidal rhythms in the horseshoe crab, Limulus polyphemus. Bull Mar Sci 36:388-395

Schindler DW, Mills KH, Malley DF, Findlay DL, Shearer JA, Daves IJ, Turner MA, Linsey GA, Cruiksha DR (1985) Longterm ecosystem stress - the effects of years of experimental acidification on a small lake. Science 228:1395-1401

Short FT, Dennison WC, Capone DG (1990) Phosphorus-limited growth of the tropical seagrass Syringodium filiforme in carbonate sediments. Mar Ecol Prog Ser 62:169-174

Small AC (1991) The ecology and cultivation of mussels: new advances. Aquaculture 94:245-261

Sornin JM, Feuillet M, Heral M, Fardeau JC (1986) Influence des cultures d'huitres Crassostrea gigas sur le cycle du phosphore en zone intertidale: role de la biodeposition. Oceanol Acta 9:313-322

Stewart RA, Gorsline DS (1962) Recent sedimentary history of St. Joseph's Bay, Florida. Sedimentology 1:256-286 
Strömgren T (1976) Growth rates of Modiolus americanus (Leach) in relation to mechanical disturbance and darkness. Bull Mar Sci 26:410-413

Turner T (1983) Facilitation as a successional mechanism in a rocky intertial community. Am Nat 121:729-738

Valentine JF, Heck KL Jr (1993) Mussels in seagrass meadows: their influence on macroinvertebrate abundance and secondary production in the Northern Gulf of Mexico. Mar Ecol Prog Ser 96:63-74

Verwey J (1952) On the ecology and distribution of cockle and mussel in the Dutch Wadden Sea, their role in sedimentation and source of their food supply. Arch Neerl Zool 10: 172-239

Widdows J, Fieth P, Worrall CM (1979) Relationships between seston, available food and feeding activity in the common

Editorial responsibility: John Lawrence (Contributing Editor), Tampa, Florida, USA mussel Mytilus edulis. Mar Biol 50:195-207

Wildish DJ, Kristmanson DD (1984) Importance to mussels of the benthic boundary layer. Can J Fish Aquat Sci 41: 1618-1625

Williams SL (1980) Experimental studies of Caribbean seagrass bed development. Ecol Monogr 60:449-469

Wright RT, Coffin RB, Ersing CP, Pearson D (1982) Field and laboratory measurements of bivalve filtration of natural marine bacterioplankton. Limnol Oceanogr 27:91-98

Young CW (1989) Distribution and dynamics of an intertidal ascidian pseudopopulation. Bull Mar Sci 112:139-146

Zieman JC (1974) Methods for the study of the growth and production of turtle grass, Thalassia testudinum. In: Cronin LE (ed) Estuarine research, Vol 1. Chemistry, biology and the estuarine system. Academic Press, New York, p 541-562

Submitted: February 21, 2000; Accepted: August 17, 2000 Proofs received from author(s): March 13, 2001 